\title{
O olho atrapalha
}

\section{The Eye Interferes}

\section{El ojo estorba \\ (conversa entre Ernesto Neto e Luiz Guilherme Vergara)}

\author{
Ernesto Neto *, Luiz Guilherme Vergara ${ }^{* *}$
}

http://dx.doi.org/10.22409/poiesis.2033.105-120

\begin{abstract}
RESUMO: A trajetória do Neto é contada pelo próprio artista com especial foco no seu projeto de "indigenização da vida", na definição de Els Lagrou, antropóloga e professora da UFRJ. A multissensorialidade de seus ambientes radicaliza o sentido público da arte como espaço de convivialidade e reencantamento. Além de atrair públicos de todas as idades, suas obras refletem um posicionamento político e ético legitimado pela total imersão e acolhimento de uma outra sabedoria de vida, fora da razão ocidental junto aos rituais do povo huni kuin, no Acre. Nesta entrevista, Neto aborda um pouco do seu deslocamento ou até mesmo distanciamento de um regime de valores centrados no consumo da produção artística para discutir visões e preocupações ambientais, econômicas e espirituais que entrecruzam os povos originais, as florestas e as ameaças atuais geradas por um governo dominado pelo capital.
\end{abstract}

PALAVRAS-CHAVE: povo huni kuin; ayahuasca; arte contemporânea; espiritualidade

\footnotetext{
* Ernesto Neto, artista multimídia carioca, vive e trabalha no Rio de Janeiro. Tem realizado inúmeras exposições no circuito internacional de arte contemporânea e seu trabalho integra as coleções de alguns dos principais museus de arte no Brasil e no exterior. E-mail: poiesis.uff@gmail.com

** Luiz Guilherme Vergara é professor associado do Departamento de Arte e do Programa de Pós-Graduação em Estudos Contemporâneos das Artes da UFF. É cofundador do Instituto MESA e coeditor da Revista MESA. E-mail: luizguivergara@gmail.com
} 
ABSTRACT: The trajectory of Neto is told by the artist himself with a special focus on his project of "indigenization of life", in the definition of Els Lagrou, anthropologist and professor at UFRJ. The multisensoriality of its environments radicalizes the public sense of art as a space of conviviality and re-enchantment. In addition to attracting audiences of all ages, his works reflect a political and ethical position legitimized by the total immersion and acceptance of another wisdom of life, outside of Western reason with the rituals of the huni kuin people in Acre. In this interview, Neto discusses a little of his displacement or even distance from a value system centered on the consumption of artistic production to discuss environmental, economic and spiritual visions and concerns that crisscross the original peoples, the forests and the current threats generated by a government dominated by capital.

KEYWORDS: huni kuin people; ayahuasca; contemporary art; spirituality

RESUMEN: La trayectoria del Neto es contada por el propio artista con especial foco en su proyecto de "indigenización de la vida", en la definición de Els Lagrou, antropóloga y profesora de la UFRJ. La multisensorialidad de sus ambientes radicaliza el sentido público del arte como espacio de convivencia y reencantamiento. Además de atraer públicos de todas las edades, sus obras reflejan un posicionamiento político y ético legitimado por la total inmersión y acogida de otra sabiduría de vida, fuera de la razón occidental junto a los rituales del pueblo huni kuin, en el Acre. En esta entrevista, Neto aborda un poco de su desplazamiento o incluso distanciamiento de un régimen de valores centrados en el consumo de la producción artística para discutir visiones y preocupaciones ambientales, económicas y espirituales que entrecruzan a los pueblos originales, los bosques y las amenazas actuales generadas por un gobierno dominado por el capital.

PALABRAS CLAVE: pueblo huni kuin; ayahuasca; arte contemporáneo; espiritualidad

Como citar: NETO, Ernesto; VERGARA, Luiz Guilherme. O olho atrapalha. Poiésis, Niterói, v. 20, n. 33, p. 105-120, jan. /jun. 2019.

doi: http://dx.doi.org/10.22409/poiesis.2033.105-120

Poiésis, Niterói, v. 20, n. 33, jan./jun. 2019. 


\section{O olho atrapalha \\ (conversa entre Ernesto Neto e Luiz Guilherme Vergara)}

Luiz Guilherme Vergara: Em um encontro com o astrofísico Rodrigo Negreiro da Física da UFF, ele comentou que estamos passando por um momento de viradas paradigmáticas na astronomia que poderiam ser equiparadas com a descoberta de Galileu através do telescópio. Naquela virada do telescópio, a humanidade passou a poder estudar os movimentos relativos dos astros e galáxias através das luzes e sofisticados sistemas de observação visual do universo. Segundo Rodrigo, estamos apenas tateando uma grande transformação sobre todo os regimes de premissas e bases de estudos do universo não mais pela visualidade, mas pelos estudos das ondas, das vibrações e dos campos magnéticos. O que nos leva a uma curiosa indagação sobre paralelismos e sinergias com as tendências experimentais das artes que se deslocam do primado visual para a multissensorialidade, em especial a sonoridade e ondas vibracionais invisíveis. O que motivou esta vinda aqui, Neto, foi exatamente a sua trajetória que acompanho há anos. Em seus primeiros trabaIhos e nossas conversas, você relatava o seu interesse na física, em especial na astrofísica e na ficção científica. Sem dúvida, já é bastante reconhecida a sua reverência aos penetráveis de Hélio Oiticica e à experiência de arquiteturas orgânicas com tecidos elásticos como epidermes e órgãos de corpos coletivos expandidos dos experimentos da Lygia Clark. Porém, com as essências e as ervas aromáticas, seus trabalhos passaram para uma sensorialidade simbólica e espiritual.

Poiésis, Niterói, v. 20, n. 33, jan./jun. 2019. 


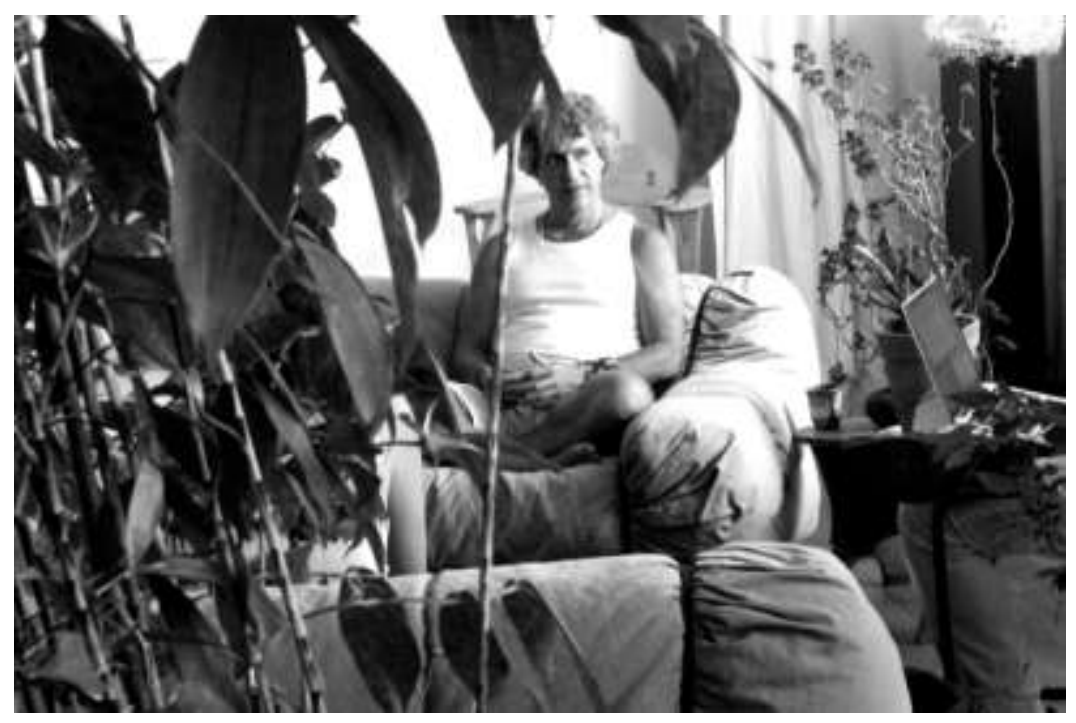

Fig. 1 - Ernesto Neto entre plantas.

(Foto: Arquivo do artista)

Poiésis, Niterói, v. 20, n. 33, jan./jun. 2019. 
O encantamento e rigor de suas estruturas suspensas no espaço inegavelmente foram se expandido como a criação de imaginários arrebatadores de sensibilidades para todas as idades.

Ernesto Neto: Então os físicos estão falando isso, é?

Luiz Guilherme Vergara: Sim. O quanto no século XX a arte vem sendo deslocada do primado retiniano? Essa dissolução da forma (já foi expressa por diferentes artistas e críticos, em especial Helio Oiticica no Suprasensorial) para explorar outras dimensões parece estar em completa ressonância com o que o Rodrigo Negreiros comentou sobre as viradas nos estudos da astronomia e da astrofísica - uma revolução ainda estar por vir: "ainda não sabemos o que vai vir, mas não será mais partindo do visual." Os estudos da astronomia estão voltados para detectores de ondas gravitacionais e sistemas vibracionais, o que representa um desvio das grandes lentes dos telescópios.

Ao ver a trajetória de seus trabalhos das malhas, as redes e tramas de crochê, pode-se reconhecer uma geometria elástica desenhada pela ação invisível do espaço dando forma as linhas de força gravitacional. [Enquanto conversávamos em sua casa, me chamava a atenção uma pequena rede - obra suspensa no teto da sala. Mas tarde perguntei ao Neto o título daquela peça. Como não tinha nome ainda, dois dias depois ele me respondeu Lagartoabretempo].

Em outras palavras, o que vemos suspenso no espaço são curvas e parábolas modeladas por forças invisíveis da lei da gravidade. Dois eixos que me chamam atenção em sua trajetória são o campo da física / astrofísica, e do corpo / comportamento multi-sensorial. Nos últimos 10 anos (talvez até menos), estas dimensões complementares deram lugar a um "pensar e intuir espiritual" que formam uma outra contundência de devir radical.

A partir dessa breve arqueologia da sua trajetória, podemos abrir esta conversa. O que está emergindo (ou atingindo) de outros campos de saberes e viveres o seu "pensamento escultórico"? 
Ernesto Neto: O que eu tenho pensado já faz um tempo, já fazem uns dois anos talvez, e muito a partir desta convivência com os povos indígenas Huni Kuin e Yawanawá, é que "o olho atrapalha". Essa foi uma frase que eu falei para o Tato [Taborda], professor do curso de artes da UFF. Eu comecei uma conversa com ele quando a gente estava na água, ali na praia do Leme. O que foi interessante, porque na água você está o tempo todo em movimento. Tem um "fluido" entre nós. Neste fluido, o ar parece vazio, mas na verdade este vazio é cheio. E este lugar do vazio vai bater nessa história do Galileu, Copérnico, essa turma toda... E do Giotto. O Giotto quando começou a desenhar uma noção de préperspectiva (ele que desencadeou essa transformação toda), essa noção só se consolidou uns 150 anos depois (não sei exatamente), porque, na verdade, o vazio, o zero, isso tudo era proibido pela Igreja. Porque representaria um vazio de Deus filosoficamente - como Deus está em todo lugar, não se podia lidar com isso. Se a gente pensar em todo o desenvolvimento que teve na Renascença, esse pensamento é fundamental - o pensamento do zero. O zero era o que faltava para os europeus conseguirem desenvolver a matemática, que já era desenvolvida pelos árabes, indianos e tal...

O fato é que a perspectiva é o grande símbolo da Renascença. E a perspectiva seria você pintar o vazio. Esse vazio que era proibido para Giotto. Então, Giotto fazia um interior perspectivo, mas no exterior ele não podia... Ele dava volumetria para os corpos, mas não dava perspectiva para a natureza. Não tinha essa transformação da natureza em paisagem que é fundamental para a ciência.

Então, da mesma forma, o que a ciência faz: ela separa a gente da paisagem e olha ela de forma analítica, gerando a ciência. O que aconteceu é que eu comecei a perceber, nessas cerimônias indígenas, que em algum momento a luz acaba. A luz acaba e todos os outros orgãos sensoriais se tornam muito mais fortes. Então esse poder, essa soberania do olho vai por água abaixo.

Essa sociedade que a gente vive é baseada no olhar. A estrutura social da Renascença pós-Iluminismo - o próprio Iluminismo - vem da luz. O microscópio mais poderoso que a ciência inventou é cego. Ele vai tateando porque é tão pequeno o que está se vendo que

Poiésis, Niterói, v. 20, n. 33, jan./jun. 2019. 
não emite luz. Então ele joga um bombardeamento de elétrons e faz uma "varredura", e com essa varredura o computador recria a forma, faz o invisível ficar visível. O olho é como se fosse o lugar da objetividade em relação aos outros orgãos sensoriais. Você olha. "Ver para crer". Meus amigos Roberto e Celina Portella propuseram outra frase: "Crer para ver". A partir da crença, você começa a ver, o que acho bem interessante...

Esse triunfo do olho é o triunfo da objetividade, da sociedade da razão, da sociedade iluminista - luz. Olho. Visão. "Você viu o que ela falou?"; "Você viu o que ele disse?"; "Como assim, você viu?". Então, o ver é uma coisa que a gente usa para provar. Se você prestar atenção, você vai ver que em vários momentos do dia você fala "você viu aquele barulho?"

Olha só - o correto é "você ouviu aquele barulho". Mas a nossa linguagem está tão impregnada da força do olhar, da força da visão, que a gente usa o "olhar" para dar uma confirmação. Então, quando você quer confirmar uma coisa, você usa a visão para comfirmar. E isso não é verdadeiro. Isso é uma fantasia que se construiu com essa sociedade da objetividade. E é interessante que a arte seja o único lugar de subjetividade dentro desta sociedade da objetividade. E que na verdade, por mais objetiva e racionalista que esta sociedade seja, as coisas não acontecem de forma racional, objetiva.

Se existe uma racionalidade é uma racionalidade muito louca; as pessoas escolhem um governador, presidente ou deputado de uma forma muito mais emocional do que de forma racional de fato. Várias atitudes que a gente toma na vida, você calcula, calcula e a decisão final é intuitiva de alguma forma. Mexe com seus ancestrais, com a sua própria história. Há um choque de realidade. Se propôs, se acreditou em uma racionalidade, em uma possibilidade racional de verificação do mundo e comportamento social, mas isso não é o que acontece.

Então eu acho que o desfalecimento dessa estrutura social, ocidental está acontecendo por essa crença, por esse "ver pra crer" na razão e no olhar, em detrimento das outras sensações. Isso tem muito a ver com a industrialização. Quando você pega e come uma fruta, essa fruta nunca tem o mesmo sabor. Mesmo aquela mesma fruta, há dois dias 
atrás, tinha um sabor diferente de hoje e daqui a dois dias terá outro, porque ela está em um processo vivo de amadurecimento. Ela continua viva. Todas as células, os microorganismos, a vida ali está se transformando, em movimento. A casca, a pele da fruta nunca é igual. Mas, se você pegar um iogurte de morango, guardadas as diferenças de receita de cada companhia, vai ter sempre o mesmo sabor. Então, os nossos filhos, que estão comendo esses produtos industrializados, estão acostumados com um paladar único. Você não vê a cor do conteúdo, porque a embalagem normalmente é opaca; você tem um desenho gráfico, uma comunicação visual mostrando que produto é aquele; dando o "ver para crer". Você olha aquele produto, você olha para aquele design e aí você acredita naquilo. Como se fosse uma coisa "Deus" - carimbo ali, você pode beber que não tem veneno não, pode provar. Só que está cheio de veneno, não é? Esse é o problema. $\mathrm{E}$ a pessoa bebe aquilo, não vê o conteúdo e se acostuma com aquele sabor. Qualquer sabor diferente daquele sabor é um incômodo para pessoa. Então, isso vai afastando a gente da natureza. Vai afastando a gente do odor, do paladar... Vai mono-politizando o nosso paladar, o nosso cheirar, todas as nossas sensações, digamos assim. A gente vai ficando mais distante destes sentidos. Você deixou de usar o seu olfato para saber se a fruta está boa; você deixou de usar seu tato para ver se a fruta está madura ou verde e o seu paladar está fixo em um lugar. Você está acreditando naquele selo de verdade universal que é o selo do produto, apoiado pelo Ministério da Saúde e estas sub-gangues patrióticas sei lá o quê..., que, de alguma forma, garantem a você que aquilo é uma coisa saudável e a gente sabe que não é. Nesse desencantamento, a gente descobriu isso, que ali está somente o veneno e a gente, na verdade, está ficando cada vez mais afastado da onde está a verdade pura e multinatural, multicultural, biodiversa, da natureza. Porque o sabor de uma fruta é biodiverso dentro dele mesmo. Então, a gente entra nesse mundo.

Mas voltando a questão do triunfo do olhar, dentro desta pesquisa [dos povos indígenas] na qual um dia ouvi "o olho atrapalha", porque o olho se tornou tão triunfante que a gente para de utilizar os outros orgãos sensoriais, em supervalorização ao olhar.

A gente precisa olhar com o terceiro olho, que é a questão da bandeira nacional. A bandeira nacional é o terceiro olho; aquilo é um kenê de um olho de pássaro, que os Huni

Poiésis, Niterói, v. 20, n. 33, jan./jun. 2019. 
Kuins chamam de "olho da Curica". Eles dizem que aquele kenê é para você ver longe. Kenê é um grafismo, a geometria sagrada dos Huni Kuins, que a gente entra em contato quando a gente toma a medicina. Se você for ver, todo o trabalho da pajelança é feito também com o canto, com a música. Todo o trabalho espiritual, seja indígena, seja afrobrasileiro, e até um trabalho europeu, cristão, os cantos orientais... A música está sempre na relação espiritual da gente com o mundo. Essa vibração é que faz a nossa conexão espiritual, é o que faz a transcendência. O tambor dos xamãs do norte da Europa, dos Samis, através da vibração do tambor eles entram em contato com o reino dos mortos para fazer a cura.

É interessante falar isso porque os tambores eram proibidos durante a escravatura americana. Porque, para os americanos, os tambores eram o som do diabo. Para a Europa, era o som da Terra - demônio. Enquanto o agudo levava para os céus, para o divino. Então, olha que loucura, colocar a terra, que é nossa mãe, que tudo nos dá, com o demônio.

Nesse encontro com os Huni Kuins e com a medicina sagrada mais conhecida como ayahuasca, que eles chamam de Nixi Pae, quando você entra nessa força da medicina e vê coisas que a planta te ensina, é a natureza falando com você. Os pajés fazem a comdução disso, mas quem está falando com você é a planta. Essas plantas, muito sábias, no caso da ayahuasca é o encontro do cipó Jagube com a Chacrona, Nixi com Kawa em Hãtxa Kuin, língua dos Huni Kuin; mas enfim, muita coisa eu fui descobrindo diante desta sociedade, uma série de coisas, por que realmente é muita luz que traz...

E aí, um dia eu estava aqui nesta sala com a Lili [Liliane Kemper], falando: "Lili, eu já entendi esta questão da cruz, mas não entendi ainda como que na tradição bíblica, a serpente, que é a luz (na cultura Huni Kuin, a serpente, a Jibóia é a conexão entre o mundo material e o espiritual, quando a gente toma a medicina é a Jibóia que ensina. $A$ gente está bebendo a Jibóia, ela está ensinando tudo. Ela que é a grande mestre, ela que é a pajé), a sabedoria, ser quem trouxe o pecado para a humanidade?" Aí cara, foi só falar isso que apareceu a resposta. Se a serpente encantada não tivesse oferecido a maça para Eva e se Eva não tivesse compartilhado-a com Adão, Adão e Eva estariam até hoje 
no paraíso, não é? Que lindo Adão e Eva no Paraíso! E a gente? Onde é que a gente estaria? Não teria a gente no mundo. Só teria Adão e Eva no paraíso.

Então, a serpente encantada, dentro dessa tradição judaico-cristã, deu à luz a humanidade - "só" isso! Ela é a mãe! Mamãe-Jibóia! Mamãe serpente encantada, como vocês quiserem chamar...

O que é uma Jibóia? É o vibracional andando pra lá e pra cá. É a coluna do infinito do Brancusi. Isso aqui [aponta para duas pulseiras de miçangas, uma em cada pulso], essa sequência de losangos que você vê aqui na cultura Yawanawá e aqui na Huni Kuin é a coluna do Brancusi para o infinito, irmão. Olha isso, cara! Brancusi é meu avô. Ele e a Lygia Clark são os dois artistas mais importantes para mim, para minha história, minha relação com o ancestral, digamos assim.

Então, quando o Antonio Bispo dos Santos (recentemente eu li um artigo muito interessante na revista Pise a Grama, de autoria deste senhor), um quilombola, resolveu procurar na bíblia o mito da criação e descobriu que, depois que Adão e Eva fizeram amor e Deus resolveu expulsá-los do paraíso e amaldiçoar a Terra, Deus disse: "Você vai ter que tirar da Terra com o suor do seu trabalho"... Mas cara, você tira uma fruta da terra sem suor do seu trabalho... A fruta está lá, você pega e come. Isso é o que o Antônio fala no artigo. Então, esse amaldiçoamento da terra, pode ter a ver com essa coisa de achar que o grave, o som do tambor, o som grave, é o som do diabo. Isso que estamos falando é uma coisa antiga, nem os europeus acreditam mais nisso... Mas, de alguma forma, isso está na ancestralidade e o agudo seria essa força que iria para o céu.

Mas independentemente disso tudo, são vibrações, que são forças que trabalham nesse nosso espiritual. Agora as consequências que isso tudo tem são enormes, inclusive politicamente, e são bastante responsáveis por toda essa "secura" que a gente está começando a viver da "não-floresta".

Ainda temos bastante floresta, ainda temos muitos pajés e é bom a gente começar a ouvir eles, e é bom ouvir também os babalorixás. Mas eu acho que neste momento, aci-

Poiésis, Niterói, v. 20, n. 33, jan./jun. 2019. 
ma de tudo, a força está com os pajés; vocês podem ver politicamente como os povos indígenas estão se organizando de maneira exemplar, com o canto e com a dança. E os africanos têm essa força também, porque eles também são povos indígenas. Eu me lembro de uma vez em que eu estava em Santiago da Compostela e vi uma manifestação (acho que na África do Sul) onde as pessoas estavam cantando e dançando. Aí eu liguei para minha irmã, que morava na Espanha, para bater um papo e disse: "vi isso na televisão aqui agora"; e ela disse: "se fosse aqui na Europa, duvido que as pessoas levariam a sério...".

O protesto é sempre uma coisa briguenta no mundo ocidental, porque segue a estrutura da guerra, a estrutura do capitalismo, a estrutura da competitividade... Isso é uma coisa tão louca que se você for ver as academias, que agora estão sendo atacadas violentamente, dentro delas também existem conflitos gigantescos, guerras absurdas de vaidade, de crítica, o trabalho de um já é a crítica do outro e tal; então, eu não sei, me parece que isso é uma representatividade da estrutura da sociedade capitalista, em que basicamente a idéia da competitividade é uma idéia de guerra. Uma empresa quer destruir a outra ... Isso é uma loucura!

Eu me lembro de uma ocasião em que encontrei um amigo com quem eu fiz um trabalho lá na Filadélfia para a The Fabric Workshop and Museum; enquanto conversávamos, comentei que, quando nos encontramos um ano antes em Washington, ele havia me falado que ele estava com uma dívida de 17 mil dólares no banco. Perguntei a ele como é que estava a dívida naquele momento (como ele nasceu na Romênia, cresceu dentro do comunismo, não tinha essa relação de competitividade e tal ) e ele disse: "agora ela está em 25 mil e você precisa ver como eles me tratam bem no banco... eles me adoram"; "Inclusive recebo várias propostas de comprarem minha dívida. Eles oferecem dois anos de juros baixos, mas se passar de dois anos fica lá no alto...". Então, você vê que interessante esse trabalho - pegam cem pessoas, conferem quanto elas recebem por mês, verificam o gasto delas, e então mandam carta para estas cem pessoas que foram qualificadas para cair nessa ratoeira, não é? É uma armadilha que eles estão mandando. Destas cem pessoas, vamos dizer que trinta caem na armadilha. É claro que eles não 
estão fazendo isso tentando ajudar o outro a pagar suas dívidas e seguir o seu caminho. Não! Estão querendo acabar com a vida do outro, colocar o outro cada vez mais nesta ratoeira. Esta é a estrutura que a gente vive. Isso está espalhado dentro do sistema dominante que é um sistema forte, competitivo, um sistema da guerra.

Na floresta, não é que as tensões não existam, no meu entender. Mas elas não são tão "racionalmente agressivas", como a gente tem aqui. Tem um lago lá na Filadélfia, para o qual o meu amigo apontou nessa ocasião e disse "ali tem um lago". Eu perguntei: "vocês nadam ali?"; ele respondeu: "não, ali a gente não nada. A gente nada ou aqui ou lá, onde tem o salva-vidas, porque é proibido nadar no lago. Só podemos onde tem o salva-vidas". É proibido nadar no lago, caso contrário você poderia processar o estado. Então, as pessoas preferem a possibilidade de processar o estado do que a liberdade de nadar no lago. Tem alguma coisa estranha, não é? Muito papel e muita caneta eu acho.

Luiz Guilherme Vergara: Você começa sua fala trazendo a questão da "quebra do domínio do olhar" que a gente está vivendo, retomando o processo de formação da razão europeia, seja com Giotto, depois com o Iluminismo, que atualiza a conversa para o campo da astrofísica que mencionei no início, na qual se anuncia uma mudança de paradigma em que uma nova astrofísica que está surgindo não será regida pelo olhar, ou pela luz, mas sim pelos campos gravitacionais, pelo estudo das ondas que habitam o espaço.

É interessante que, neste momento, você esteja completamente alinhado com esse tema, como se estivesse seguindo um devir... Achei ótimo também você trazer essa visão da serpente e como ela foi transformada em uma geradora do medo? Ela é a conexão. O símbolo da medicina são duas serpentes, assim como o da Kundalini. O símbolo da Kundalini são duas serpentes que se entrelaçam, que são a razão e a sensibilidade.

Ernesto Neto: Que é o DNA, irmão! O DNA são duas serpentes em espiral com uma escadinha; elas fazem essa conexão do espiritual ligadas por quatro aminoácidos. Então, um livro maravilhoso para se ler sobre isso que foi editado agora pela editora Dantes em

Poiésis, Niterói, v. 20, n. 33, jan./jun. 2019. 
português é $A$ Serpente Cósmica - o DNA e a Origem do Saber. Agora, isso que você está falando sobre essa transformação que está acontecendo na física, pelo que eu estou entendendo, acompanha uma transformação que está acontecendo na Terra.

A Terra está se modificando e está entrando uma coisa que pode ser vista de várias maneiras, uma delas é a força feminina, muito grande, de transformação; a força das florestas; a força dos pajés; a força das culturas ancestrais, e tudo isso está ligado a esta questão de vibração porque os desenhos, todo os kenês, todo o grafismo indígena branco, preto, branco, preto - é esta vibração que vai andando "pra cá e prá lá".

Que aparentemente são positivo e negativo, mas positivo e negativo, neste caso indígena, não é como essas oposições com o sagrado e o profano. É tão interessante (e mórbido, ao mesmo tempo) como o cristianismo se apodera de um profano e coloca o profano em um lugar da sombra, quando na verdade essa sombra também é luz.

Se você pensar que a gente acabou de passar pela semana santa; a semana santa, você sabe porque que ela flutua? Porque ela vai "pra cá e prá lá"? Estamos falando de astrofísica - porque ela acontece na primeira lua da primavera. Da primavera européia, não da primavera brasileira. Então na primeira lua da primavera, durante o fim de semana, tinham as festas da Renascença, do renascer, do ressurgir, e estas festas e datas foram abduzidas pela cultura cristã.

Mas esses escuro e claro andam juntos; é a jibóia andando para lá e para cá, para além do bem e do mal, essa perspectiva nietzschiana - o Nietzsche é bem importante para gente hoje em dia, as coisas que ele previu estão todas acontecendo - nesse desencantamento que está acontecendo com a "sociedade do olhar", que está desencantando e talvez se transformando nessa sociedade vibracional. Onde não será - talvez - a razão, a grande mestra conduzindo a nossa sociedade, talvez vá se abrir um espaço para o amadurecimento intuitivo da nossa sociedade como um todo, sociedade humana na Terra, onde aqueles povos que foram culturalmente massacrados, não só no sentido material, mas no sentido espiritual, cultural, eles terão respostas - já tem, não é? - para essa nova humanidade, essa humanidade vibracional. 
A gente espera que dê tempo, não é? Porque existe um conflito muito grave onde o Brasil está sendo o protagonista maior através de um ser, coitado, de muita pouca luz. Os mexicanos diriam "um ser de muita pouca pluma". Os mexicanos dizem que "aquela pessoa não é má ou boa, aquela pessoa está com poucas plumas; a medida que ela for colocando plumas no corpo dela e se tornar uma grande pessoa emplumada, as coisas se transformam". Então, essa pessoa de pouca pluma está com a pluma oficial dela dando umas "canetadas" por aí, que estão abrindo espaço para uma detonação muito grande, sabe-se lá, irreversível. Eu não acredito nisso, porque eu acho que essa sombra já era prevista.

A gente está em uma transformação de luz muito grande, é uma transformação cultural gigantesca. A dimensão de humanidade que pode surgir dessa transformação é muito grande. E assusta profundamente. São modos de vida muitos diferentes. Eu e muitas pessoas já estávamos sentindo. Pelo menos agora está claro. Quando a genealogia do golpe começou a aflorar sobre a Terra Brasilis, a gente já estava vendo isso. "Ele" e sua gangue, protagonistas de um universo muito rudimentar, emergiram deste cataclisma. Este momento de agora traz luz ao que estava oculto. Por pior que possa aparecer, a eleição desse sujeito está trazendo luz para ver que gente como ele existe mesmo. E muito. E toda uma infraestrutura socioeconômica aproveitadora - é a tal escravocracia.

É o que apareceu para mim e que resultou na escultura chamada Cura Bra Cura Té, que está sendo exposta dentro da exposição Sopro na Pinacoteca em São Paulo. A gente vive em uma estrutura de escravocracia, em uma "forma" avançada deste pensamento, onde as pessoas estão sendo acorrentadas, chicoteadas e assassinadas. Muitas delas estão em maior situação de fragilidade nas comunidades, as minorias que são maiorias, a floresta os mais pobres, pretos e indígenas. E essa gente é que tem a cultura da salvação, por mais cristã e estranha que possa parecer essa palavra; trazem uma cultura muito enriquecedora, que tem muita sabedoria.

Luiz Guilherme Vergara: Ontem nós vimos um filme - What is emerging? - que fala desse campo de percepção de reconectar, que é religar, esse religar de outras formas de ra-

Poiésis, Niterói, v. 20, n. 33, jan./jun. 2019. 
zão. Me chama atenção a sua fala sobre as manifestações de indignação africanas e indígenas com dança e música, e quando você fala também da música na história da humanidade como sendo aquilo que transforma nosso sensorial por vibrações; são estas outras razões, sejam as de raiz africana ou indígenas, que são portadoras de uma outra semsibilidade. Também o ataque às universidades - estamos atacando aquilo que pode produzir transformação. É um momento muito delicado para que a gente não caia na armadilha de um enfrentamento que eles desejam, que é o enfrentamento com a violência. Então, esse campo de virada planetária - hoje alguns termos estão sendo ditos e merecem a nossa atenção: o surgimento de uma escola planetária. Representada por artistas como você, Neto, e outros que cruzam vários saberes dentro da própria arte, que esgarçam o que é arte e o que não é fazendo uso de outros saberes. Então o seu trabalho, Neto, é trazer para o trabalho aquilo que o Mário Pedrosa chamou de "instrumentos de síntese". A cultura européia segue uma lógica de separação. Quando você fala sobre a separação de cultura e natureza, corpo e espírito, separar, separar...

A própria academia incorporou o pensamento competitivo, no qual para eu estar certo, eu tenho que provar que você está errado. Não há, dentro dessa razão acadêmica européia, a possibilidade de $\mathrm{A}$ estar certo e $\mathrm{B}$ também. A possibilidade de síntese. Então a arte está cumprindo um papel, neste momento de crise, como Mário Pedrosa previu ou recuperou ao longo do século XX, de "instrumento de síntese".

Ernesto Neto: Então, você tocou em um ponto que me inspira a me reposicionar porque, para mim, se trata de uma das coisas mais delicadas que a gente está abordando aqui e agora. Porque realmente, a cultura está sendo atacada violentamente e um dos protagonistas deste ataque é a igreja evangélica, ou uma parte deste campo, a parte mais poderosa. Basicamente, o lugar da espiritualidade (a igreja) está sendo crítico ao pensamento da cultura. Se a gente está colocando que a espiritualidade é a grande força transformadora, tomando como exemplo os povos indígenas e africanos (pajés, babalorixás...), a gente está falando da conexão de um mundo material com o espiritual; então existe, 
neste caso, a espiritualidade libertadora e existe, no caso da igreja evangélica, a espiritualidade utilizada, como disse a Suely Rolnik, para sequestrar e anular a subjetividade.

Existe também, operada por este mesmo campo, uma crítica à intelectualidade, uma intelectualidade maravilhosa e necessária, mas que padece de uma competitividade e que, assim como a arte, se torna tão distante da sociedade que deixa de ter poder de transformação na sociedade e se torna uma coisa clubista, vaidosa. De um grupo de privilegiados que têm acesso a uma cultura que é uma conversa pequena. Tem um jogo muito sutil que está acontecendo. Se você fala isso e aquilo, você é comunista e ser comunista, aparentemente, é uma coisa ruim (eu tenho as minhas dúvidas). Mas o que eu não tenho dúvidas é que esses "istas", seja comunista, capitalista, socialista e tal, estão como uma dificuldade de se manter nesta estrutura de pensamento. E o problema que a democracia enfrenta é que ela sempre é uma luta pelo poder.

A conversa entre Ernesto Neto e Luiz Guilherme Vergara foi realizada no dia 11 de maio de 2019, como parte das atividades do grupo de pesquisa Interfluxos experimentais contemporâneos entre arte e sociedade, liderado por Luiz Guilherme Vergara. O encontro contou com a participação especial de Lívia Moura, Gabriela Bandeira e Daniela Moreira. 